\title{
Utilisation of Copper Slag Waste and Heavy-Weight Aggregates for Production of Pre-cast Shielding Concrete Elements
}

\section{Wojciech Kubissa*, Roman Jaskulski}

Faculty of Civil Engineering, Mechanics and Petrochemistry, Warsaw University of Technology 17 Łukasiewicza St., 09-400 Płock, Poland

\section{Pui-Lam Ng}

Faculty of Civil Engineering, Vilnius Gediminas Technical University Sauletekio ave. 11, LT-10223 Vilnius, Lithuania

\section{Jiajian Chen}

Department of Civil Engineering, Foshan University, 528000 Foshan, China

*Corresponding author: wojciech.kubissa@pw.edu.pl

\section{$\Gamma$} crossef $h t t p: / / d x . d o i . o r g / 10.5755 /$ j01.sace.22.1.20006

Concrete as a versatile building material can provide physical and biological shielding against ionizing radiation. In addition to nuclear reactor covers, facilities requiring radiation protection are radiological and X-ray laboratories in hospitals or health centres. The function of radiation protection can be met by heavy-weight concrete, whose shielding properties are largely derived from the high-density aggregates. One of the possible construction methods of shielding walls in healthcare buildings is the use of pre-cast concrete blocks. For this purpose, research on a concrete having a density in the air-dry state of higher than $3200 \mathrm{~kg} / \mathrm{m}^{3}$ using barite, magnetite and basalt as coarse aggregate and copper slag waste (from by-product of the process of copper extraction by smelting) as fine aggregate has been performed. The copper slag waste has been used, among others, as an abradant in the surface sandblasting process but after such usage it is considered to be a waste and as indicated by pilot research, it can be a good substitute for sand in concrete. Mechanical properties, water absorption and sorptivity of heavy-weight concrete so produced were compared with reference concrete prepared with crushed amphibolite as coarse aggregate and quartz sand as fine aggregate.

The suitability of copper slag waste for making small pre-cast shielding concrete elements is confirmed. The compressive strength of heavy-weight concrete mixtures with copper slag waste was sufficient for the intended applications. The copper slag concrete had lower water absorption and sorptivity than concrete prepared with sand. An economic analysis of the costs of producing concrete with a density higher than $3200 \mathrm{~kg} / \mathrm{m}^{3}$ with or without copper slag waste showed that the copper slag concrete, regardless of the type of heavy-weight aggregate used, is clearly more economical than the concrete of the compositions reported in the literature containing similar coarse aggregates and sand as the fine aggregate.

Keywords: amphibolite, barite, basalt, copper slag, heavy-weight aggregate, magnetite, shielding concrete.
JSACE $1 / 22$

Utilisation of Copper

Slag Waste and Heavy-Weight

Aggregates for

Production of

Pre-cast Shielding

Concrete Elements

Received

2018/01/22

Accepted after

revision

2018/05/31

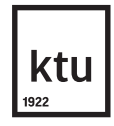

Journal of Sustainable Architecture and Civil Engineering Vol. 1 / No. 22 / 2018 pp. 39-47

DOI 10.5755/j01.sace.22.1.20006 (c) Kaunas University of Technology 
Concrete, because of its characteristics and ease of shaping into variable forms, is a versatile building material that can act as physical and biological shield against ionizing radiation (Glinicki 2015, Piotrowski and Gryziński 2016). At the same time the shielding concrete can fulfil structural functions. In addition to reactor covers, enclosures and other applications in nuclear power plants, facilities requiring radiation protection are radiological and X-ray laboratories in hospitals or health centres. The function of radiation protection (in the latter case mainly $\mathrm{X}$-ray) can be met by heavy-weight concrete. Shields made of heavy-weight concrete are described as a passive protection, for which a typical purpose is to reduce the level of radiation to levels safe for the operational personnel and users in the premises (Saferna and Kaszuba 2003, Ouda 2015).

The criteria for selection of ingredients and concrete mix design for shielding structures include effectiveness of shielding against ionizing radiation, mechanical and physical properties, and impermeability to liquids and gases (Bamonte and Gambarova 2014, Kurtis et al. 2017). The significance of cement selection for radiation shielding concrete was discussed by Baran et al. (2016). The permeability requirement of the shielding concrete is dependent on the applications. For example, the impermeability is particularly important in the case of a nuclear power plant where the leakage of radioactive gases must be protected against. For other applications, the low permeability of concrete, especially regarding to liquids, helps to prevent the penetration of harmful substances into and out of the structures.

The compressive strength requirement of the shielding concrete is generally not high, it is often the class C20/25 or C25/30 according to European Standard EN 206 (Saferna and Kaszuba 2003). To manufacture shielding concrete, usually special heavy aggregates such as barite, magnetite or hematite are used (Brandt 2013). These special aggregates, generally made of soft rocks, have sometimes unfavourable gradation and a high content of dust. This causes an increase of water demand and technological difficulties in the manufacturing and compaction of concrete mixes (Glinicki 2015). There is also a risk of segregation of the components of the mixture alongside its production, transport or compaction (ACl 221R-96 1997, ACl 304.3R-96 2004, Glinicki 2015). Possible segregation of concrete components could result in significant non-uniformity and heterogeneity which can lead to local radiation surges and failure of shielding.

One of the possible solutions for the construction of shielding walls in healthcare buildings is the use of pre-cast concrete blocks. In the case of a structure with uncomplicated shape, such as a planar shielding wall, the use of small prefabricated elements allows higher flexibility in concrete placement, transportation and on-site handling. Concrete mix can be designed to have even a higher consistency, compared to the case of ready-mixed concrete that needs to cater for the transport, pumping and in-situ casting of monolithic walls. The pre-cast method limits the risk of segregation of the mixture components during placement and compaction. The use of pre-cast blocks also allows for faster wall construction than in-situ concreting. The wall built from the blocks can be dismantled with relative ease and this allows the material to be re-used elsewhere.

Fine aggregate used in the shielding concrete is often sand, whose density is substantially lower than the density of the heavy aggregates used as coarse aggregate. To minimise the segregation risk, theoretically it is more appropriate to use fine aggregate of higher density. A viable solution would be the use of copper slag, which has a higher density than sand (approximately $3000 \mathrm{~kg} / \mathrm{m}^{3}$ ). Copper slag is a by-product during the process of copper extraction by smelting. It is a nearly inert material in concrete and its physical properties are similar to natural sand (Meenakshi Sudarvizhi and llangovan 2011). It is used, among others, as an abradant in the surface sand-blasting process but after such usage it is considered to be a waste. As indicated by pilot research, copper slag should be a good substitute for sand in concrete (Ayano and Sakata 2000, Al-Jabri et al. 2011, Alp et al. 2008, Kubissa et al. 2017). It is possible to utilise waste copper slag 
for the production of high-quality concrete, improving its properties compared to concrete batched with sand (Al-Jabri et al. 2009, Ambily et al. 2015). Due to mechanical abrasion, the copper slag particle size after surface blast-cleaning process becomes finer. The content of $0-0.125 \mathrm{~mm}$ and $0.125-0.25 \mathrm{~mm}$ fractions is significantly increased. Typically the waste copper slag also contains a small amount of corrosion products and corrosion protection coatings (Rzechuta 1994). The copper slag could potentially enhance the abrasion resistance of concrete, though the abrasion resistance of pre-cast blocks is not of prime importance. Nevertheless, for shielding concrete which is subjected to abrasive degradation, the abrasion resistance improvement by copper slag would be important from durability viewpoint. An example of the use of heavy-weight concrete requiring abrasion resistance is containers for transporting radioactive waste.

The purpose of the research undertaken by the authors is to develop a concrete having a density in the air-dry state of higher than $3200 \mathrm{~kg} / \mathrm{m}^{3}$ using barite, magnetite and basalt as coarse aggregate and copper slag as fine aggregate. Mechanical properties and sorptivity of such heavy concretes were compared with reference concrete prepared with coarse amphibolite aggregate and sand. To test the impact of copper slag addition, and to study the change of mixture consistency, the concrete with amphibolite and copper slag was also prepared. Consistency of this concrete was similar to concrete with barite and magnetite/basalt aggregates.

Portland cement CEM I 42.5R complying to European Standard EN 197 supplied by Górażdże Cement Plant was used. The following types of coarse aggregates were used:

- magnetite aggregate with $0-16 \mathrm{~mm}$ fraction $\left(4800 \mathrm{~kg} / \mathrm{m}^{3}\right.$ in density),

barite aggregate with $0-16 \mathrm{~mm}$ fraction $\left(4200 \mathrm{~kg} / \mathrm{m}^{3}\right.$ in density),

basalt aggregate with $8-16 \mathrm{~mm}$ fraction $\left(2900 \mathrm{~kg} / \mathrm{m}^{3}\right.$ in density),

amphibolite aggregate (for reference concrete) with 2-8 $\mathrm{mm}$ and 8-16 $\mathrm{mm}$ fractions $\left(2900 \mathrm{~kg} / \mathrm{m}^{3}\right.$ in density).

As fine aggregate, sand and copper slag of $0-2 \mathrm{~mm}$ size fraction were used.

Aggregate crushing value (ACV) of coarse aggregate was determined in accordance with Polish Standard PN-B-06714-40:1978 (similar to British Standard BS 812-110:1999 but with metrical set of sieves). Crushing resistance of the coarse aggregates was as follows: for barite, the ACV was 25.60 for $4-8 \mathrm{~mm}$ fraction and 36.04 for $8-16 \mathrm{~mm}$ fraction; for magnetite, the ACV was 6.10 for $4-8 \mathrm{~mm}$ fraction and 6.37 for $8-16 \mathrm{~mm}$ fraction; for amphibolite, the ACV was 2.66 for $4-8 \mathrm{~mm}$ fraction and 5.07 for $8-16 \mathrm{~mm}$ fraction; for basalt, the ACV was 1.97 for $8-16 \mathrm{~mm}$ fraction. A higher value of ACV implies a lower crushing resistance.

In the design of concrete mixes, a constant amount of cement $300 \mathrm{~kg} / \mathrm{m}^{3}$ was used, and the water to cement ratio $(\mathrm{w} / \mathrm{c})$ was 0.48 . Superplasticizer Chryso Optima 100 was used with the dosage of $1.0 \%$ to $1.5 \%$ by mass of cement. The composition of the concrete mixtures is given in Table 1 . In the table, the mixture labelled M contained magnetite and basalt coarse aggregate and copper slag as fine aggregate, the mixture labelled Ba contained barite coarse aggregate and copper slag as fine aggregate, the mixture labelled R-P contained amphibolite coarse aggregate and sand as fine aggregate, and the mixture labelled R-CS contained amphibolite coarse aggregate and copper slag as fine aggregate.

The consistency was measured in terms of the cone slump value and bulk density of the mixtures was determined by standard methods. With the exception of mixture R-P, the slump value was low. This is acceptable as the concrete mixes are designated for the manufacturing of small pre-cast elements, where high workability is not required. A significant difference in the consistency of concrete mixtures R-P and R-CS is caused by a much higher content of fine particles in the copper slag. 


\begin{tabular}{|c|c|c|c|c|c|}
\hline \multirow{2}{*}{$\begin{array}{r}\text { Table } 1 \\
\text { Composition }\left[\mathrm{kg} / \mathrm{m}^{3}\right] \text { of } \\
\text { concrete mixes }\end{array}$} & \multirow{2}{*}{ Components } & \multicolumn{4}{|c|}{ Mixture ID } \\
\hline & & M & $\mathrm{Ba}$ & $R-P$ & $\mathrm{R}-\mathrm{CS}$ \\
\hline & Cement CEM I 42.5 & 300 & 300 & 300 & 300 \\
\hline & Sand 0-2 mm & -- & -- & 661 & -- \\
\hline & Copper slag 0-2 mm & 678 & 441 & -- & 745 \\
\hline & Amphibolite $2-8 \mathrm{~mm}$ & -- & -- & 504 & 504 \\
\hline & Amphibolite 8-16 mm & -- & -- & 965 & 963 \\
\hline & Magnetite $0-16 \mathrm{~mm}$ & 1978 & -- & -- & -- \\
\hline & Barite $0-16 \mathrm{~mm}$ & -- & 2557 & -- & -- \\
\hline & Basalt 8-16 mm & 340 & -- & -- & -- \\
\hline & Water & 144 & 144 & 144 & 144 \\
\hline & Superplasticizer & 3.0 & 3.0 & 3.0 & 4.5 \\
\hline & & neter a & ties & & \\
\hline & $\mathrm{w} / \mathrm{c}$ ratio & 0.48 & 0.48 & 0.48 & 0.48 \\
\hline & Bulk density [kg/m³] & 3444 & 3445 & 2578 & 2660 \\
\hline & Slump [mm] & 10 & 10 & 190 & 10 \\
\hline
\end{tabular}

\section{Compressive and tensile splitting strength test}

The compressive strength test was conducted on $100 \mathrm{~mm}$ cube specimens after 28 days of hardening. The measurements were carried out in accordance with European Standard EN 123903. The tensile splitting strength test was conducted for the same type of specimens in accordance with European Standard EN 12390-6. Both tests were performed using a compression machine ToniTechnik ToniPACT II with $3000 \mathrm{kN}$ capacity. The rate of loading was controlled at $0.5 \mathrm{MPa} / \mathrm{s}$ for compressive strength test and $0.05 \mathrm{MPa} / \mathrm{s}$ for splitting test.

\section{Sorptivity test and free water absorption measurement}

The sorptivity test was conducted on the halves of cubic specimens of $100 \mathrm{~mm}$ edge by means of the mass measurement method. At first the specimens had been saturated with water for about 14 days, then their surfaces were wiped dry and weighed, and subsequently oven-dried to stable mass at the temperature of about $105^{\circ} \mathrm{C}$. The mass differences were determined to calculate the values of free water absorption. The measurements of sorptivity were conducted at the temperature of approximately $20^{\circ} \mathrm{C}$. The specimens were weighed and then placed in the vessel with water, where the specimens were dipped up to the depth of $3 \mathrm{~mm}$. In specific time intervals from the beginning of the test, the specimens were wiped to be surface dry and weighed again to define their weight gain resulting from water absorption. Subsequent weight measurements were conducted for 6 hours. The sorptivity $S$ in $\mathrm{g} /\left(\mathrm{cm}^{2} \cdot \mathrm{h}^{0.5}\right)$ was defined as the slope of the linear function expressing the dependence of the mass of water absorbed $\Delta m$ by the area $F$ on the time root $t^{0.5}$ (Eq. 1) (Kubissa and Jaskulski 2013):

$$
\frac{\Delta m}{F}=S \cdot t^{0.5}
$$


The free water absorption is calculated on the basis of (Eq. 2):

$$
n=\frac{m_{s}-m_{d}}{m_{d}} \times 100 \%
$$

where:

$n$ - free water absorption [\%],

$m_{s}-$ mass of a fully soaked specimen [g],

$m_{d}-$ mass of a specimen dried to stable mass [g].

The mass of a fully soaked specimen was measured after 28 days curing in water.

\section{Bohme abrasion test}

The test was performed according to Polish Standard PN-EN 1340. For each concrete mix, four $70 \times 70 \times 70 \mathrm{~mm}$ specimens were tested. Specimens were obtained by sawing the $150 \mathrm{~mm}$ cubes, and the tests were carried out between 40 and 45 days after concreting. Just before the test the specimens were dried in an oven at $105^{\circ} \mathrm{C}$ to stable mass. The specimens were then weighed at $0.1 \mathrm{~g}$ accuracy and the thickness in nine points was measured before and after the abrasion procedure.

The test results are presented in Table 2. In the table, each value is an average of six measurements. Confidence intervals were also provided with a confidence factor of 0.95 . In analysis of the results, the mixture $\mathrm{R}-\mathrm{P}$ with amphibolite coarse aggregate and sand as fine aggregate was used as the reference concrete.

\begin{tabular}{l|c|c|c|c}
\hline \multirow{2}{*}{ Properties } & \multicolumn{4}{c}{ Mixture ID } \\
\cline { 2 - 5 } & $\mathrm{M}$ & $\mathrm{Ba}$ & $\mathrm{R}-\mathrm{P}$ & $\mathrm{R}-\mathrm{CS}$ \\
\hline Compressive strength $f_{c}$ at 28d [MPa] & $37.9 \pm 2.2$ & $39.2 \pm 2.4$ & $43.3 \pm 4.5$ & $50.3 \pm 2.2$ \\
\hline Compressive strength $f_{c}$ at 90d [MPa] & $52.4 \pm 4.0$ & $48.7 \pm 2.8$ & $52.0 \pm 2.8$ & $65.0 \pm 3.0$ \\
\hline Tensile strength $f_{t}$ at $28 \mathrm{~d}[\mathrm{MPa}]$ & $2.82 \pm 0.37$ & $2.42 \pm 0.17$ & $3.86 \pm 0.22$ & $3.86 \pm 0.09$ \\
\hline Water absorption [\%] & $3.36 \pm 0.07$ & $3.06 \pm 0.08$ & $4.34 \pm 0.11$ & $3.96 \pm 0.09$ \\
\hline Sorptivity S [cm/h0.5] & $0.035 \pm 0.003$ & $0.034 \pm 0.004$ & $0.083 \pm 0.003$ & $0.041 \pm 0.004$ \\
\hline Bohme abrasion [mm] & $4.43 \pm 0.27$ & $8.33 \pm 0.46$ & $2.57 \pm 0.32$ & $2.64 \pm 0.32$ \\
\hline Porosity (calculated) [\%] & $11.2 \pm 0.22$ & $10.2 \pm 0.25$ & $10.7 \pm 0.27$ & $10.1 \pm 0.22$ \\
\hline
\end{tabular}

\section{Results}

Table 2

Test results

The compressive strength of the reference concrete after 28 days was $43.3 \mathrm{MPa}$. By replacing sand with copper slag, mixture R-CS (concrete with amphibolite coarse aggregate and copper slag as fine aggregate) had a higher strength by $16.2 \%$. The heavy-weight concrete mixtures $M$ and $\mathrm{Ba}$ had lower 28-day compressive strength than the reference. The percentage differences were $9.3 \%$ for mixture $\mathrm{Ba}$ (concrete with barite aggregate) and $12.5 \%$ for mixture $\mathrm{M}$ (concrete with magnetite and basalt aggregate). Nevertheless, the strength of heavy-weight concrete for both mixtures $\mathrm{M}$ and Ba was sufficient for the intended applications. The increase in compressive strength at the age of 90 days compared to the strength at 28 days was $38.3 \%, 24.2 \%$, $20.1 \%, 29.2 \%$ for concrete mixtures M, Ba, R-P, R-CS respectively. The increase in compressive strength would be due to the hydration of unhydrated cement beyond the 28-day age, as well as the limited pozzolanic reactivity of copper slags. The 90-day compressive strength of the 
reference concrete was $52.0 \mathrm{MPa}$. Comparatively, mixture R-CS had a higher strength by $25.0 \%$. The heavy-weight concrete with barite had lower 90-day strength than the reference, with a percentage difference of $6.3 \%$. The 90 -day strength of heavy-weight concrete with magnetite and basalt aggregate was $0.8 \%$ higher than the reference.

The tensile strength of concrete with amphibolite coarse aggregate, regardless of the type of fine aggregate was the same and was equal to $3.86 \mathrm{MPa}$. The strength of the concrete with magnetite/ basalt and barite coarse aggregate were lower by $26.9 \%$ and $37.3 \%$, respectively.

The sorptivity of the reference concrete was $0.083 \mathrm{~cm} / \mathrm{h}^{0.55}$, which allows to classify it as "good" according to the criteria for the classes of durability given in Kubissa (2016). Sorptivity of concrete with copper slag was much lower. The percentage differences were $50.6 \%$ for concrete mixture R-CS with amphibolite and $57.8 \%$ and $59.0 \%$ for concrete mixtures $\mathrm{M}$ and Ba with magnetite/ basalt and barite aggregates, respectively. The values obtained from these concrete mixtures determine their durability class as "very good".

The water absorption of the reference concrete was 4.34\%. Water absorption of concrete with copper slag was lower. The percentage difference for concrete mixture R-CS with amphibolite aggregate was $8.8 \%$, while the water absorption of heavy-weight concrete mixtures $\mathrm{M}$ and Ba was $22.5 \%$ and $29.6 \%$ lower than the reference concrete, respectively. The much lower water absorption and sorptivity of mixtures $\mathrm{M}, \mathrm{Ba}$ and R-CS than reference mixture R-P is believed to be due to the absence of sand, which absorbs water. The comparatively even lower water absorption and sorptivity of mixtures $\mathrm{M}$ and $\mathrm{Ba}$ than mixture R-CS is believed to be due to the water absorption of magnetite and barite aggregates (about $0.2 \%$ ) are lower than that of amphibolite and basalt aggregate (about 0.5\%).

Porosity of the concrete was calculated on the basis of free water absorption results and density measurements. The porosity of mixture M was $4.67 \%$ higher than the reference. The porosity of mixture R-CS and Ba were lower than the reference. The percentage differences were $5.60 \%$ for concrete mixture R-CS with amphibolite and $4.67 \%$ for concrete mixture Ba with barite aggregate, respectively. Nevertheless, it is noted that the percentage differences in porosity are much lower than the percentage differences in water absorption.

The reference concrete had the highest Bohme abrasion resistance. The decrease in sample height during the test was $2.58 \mathrm{~mm}$. Concrete mixture R-CS had a comparable abrasion resistance to the reference, with a percentage difference of $2.7 \%$. The heavy-weight concrete mixtures $M$ and Ba had significantly lower abrasion resistance than the reference with the percentage differences being $72.4 \%$ and $224.1 \%$, respectively. However, there was no apparent correlation between the aggregate $\mathrm{ACV}$ and the concrete abrasion resistance.

With reference to the results of ACV reported above, the heavy-weight aggregates had relatively low resistance to crushing. For example, ACV values of barite are higher than reported values of typical virgin rock aggregates and recycled aggregates (Koper et al. 2015, Jaskulski et al. 2017). This means the barite coarse aggregate had lower crushing resistance than typical virgin rock and recycled aggregates. ACV values for magnetite are lower than those of barite, but are still considerably higher than the reported value of typical good quality virgin rock aggregates. The low crushing resistance of heavy-weight aggregate might result in lower mechanical properties of shielding concrete compared to reference concrete, and this may affect the compressive and tensile strength as well as the abrasion resistance. The test results suggest that the compressive strength is closely related to the abrasion resistance of the aggregate and concrete. 
An economic analysis of the costs of producing concrete with a density higher than $3200 \mathrm{~kg} / \mathrm{m}^{3}$ with or without copper slag is carried out. It was assumed that the price of cement is $95 \mathrm{EUR} / \mathrm{ton}$, the price of barite is $180 \mathrm{EUR} /$ ton, and the price of magnetite is $260 \mathrm{EUR} /$ ton (Brandt et al. 2014). The cost of sand was taken as $7 \mathrm{EUR} /$ ton, and price of basalt aggregate is $17 \mathrm{EUR} / \mathrm{ton}$. In addition to the concrete mixes produced in this study, compositions of other heavy-weight concrete mixes from the literature (Lim 1971, Saferna and Kaszuba 2003, Ouda 2015, Dąbrowski et al. 2016, Kubissa and Glinicki 2017) are included for comparison.

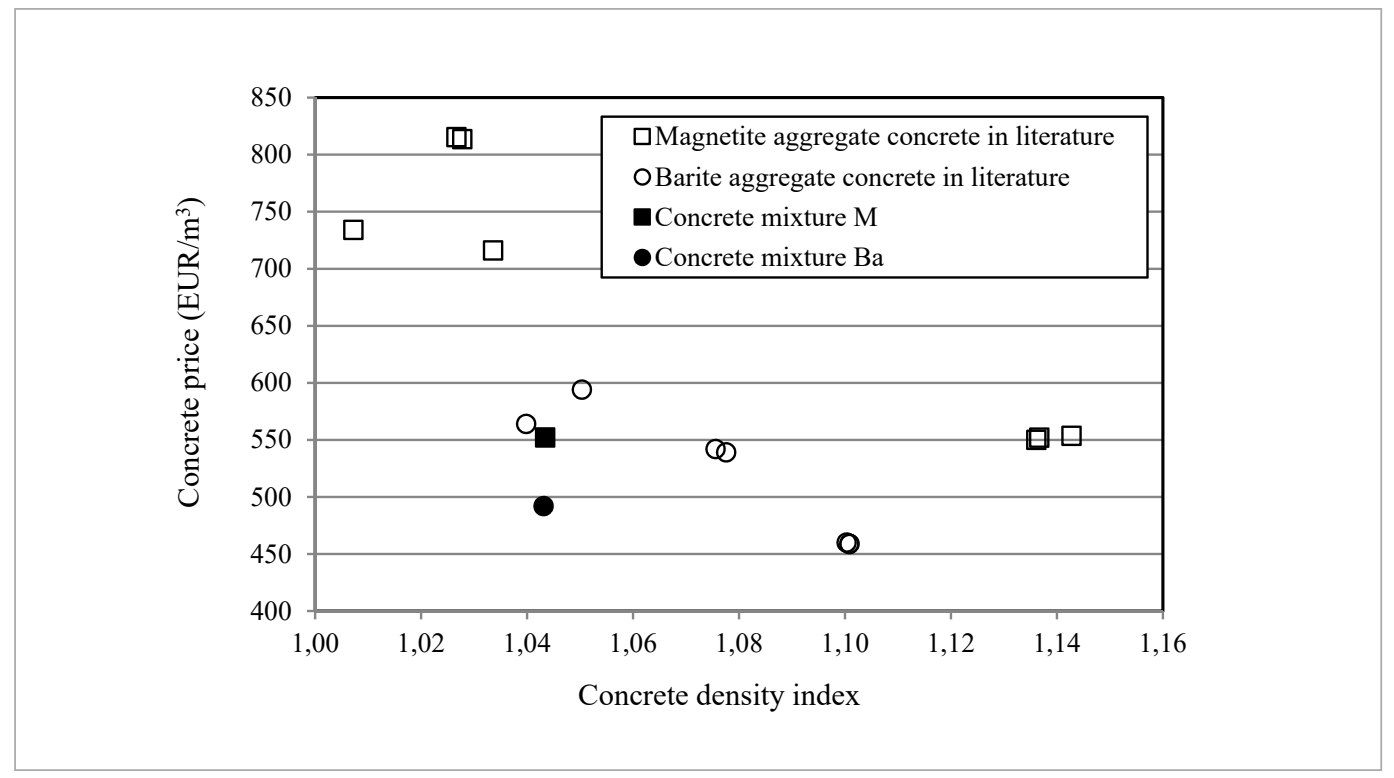

The functional criteria for evaluating shielding concrete encompass a number of attributes, but most of them can be evaluated in the binary way: the requirement is fulfilled or not. One of the most important functional features of heavy concrete is its density. Usually among the imposed requirements, the density can be used in the assessment of the cost-effectiveness of the concrete mixtures. An appropriate dimensionless index may be used for this purpose (Brandt and Marks 1996, Kubissa and Glinicki 2017). It is named the concrete density index: $1-\left(\rho-\rho_{\text {ref }}\right) / \rho_{\text {ref }}$, where $\rho$ is the bulk density according to Table 1 and $\rho_{\text {ref }}$ is the reference maximum density (arbitrarily taken as $3600 \mathrm{~kg} / \mathrm{m}^{3}$ ). Figure 1 plots the price (in EUR/ $\mathrm{m}^{3}$ ) against the density index of the concrete mixes. The copper slag concrete, regardless of the type of heavy-weight aggregate used, is clearly more economical than the concrete of the compositions reported in the literature containing similar coarse aggregates and sand as the fine aggregate.

Experimental investigation on radiation shielding concrete with copper slag waste for small precast elements applications has been performed. Based on the experimental results, the following conclusions are drawn:

With the use of copper slag as fine aggregate, it is possible to produce heavy-weight concrete with a wet consistency suitable for manufacturing prefabricated elements with uncomplicated shape.

Concrete with copper slag have lower water absorption and sorptivity than concrete prepared with sand. The measured water absorption and sorptivity indicated that the concrete mixes can be classified as very good durability class. Compared to the refer-
Fig. 1

Concrete price plotted against concrete density index 
ence concrete mixture R-P, the sorptivity were $57.8 \%, 59.0 \%$ and $50.6 \%$ lower and the water absorption were $22.5 \%, 29.6 \%$ and $8.8 \%$ lower for concrete mixtures $\mathrm{M}, \mathrm{Ba}$ and $\mathrm{R}$-CS, respectively.

The concrete mixes with barite, magnetite and basalt aggregate are more cost-effective than other heavy-weight concrete compositions reported in the literature. It is evident that at similar concrete density index, concrete mixtures $\mathrm{M}$ and $\mathrm{Ba}$ are more economical with lower prices.

\section{References}

ACl 221R-96. Guide for Use of Normal Weight and Heavyweight Aggregates in Concrete. Detroit, Ml; 19

ACl 304.3R-96. Heavyweight Concrete : Measuring, Mixing, Transporting, and Placing Reported by $\mathrm{ACl}$ Committee 304. Detroit, Ml; 2004

Al-Jabri KS, Al-Saidy AH, Taha R. Effect of copper slag as a fine aggregate on the properties of cement mortars and concrete. Construction and Building Materials. 2011; 25(2): 933-938 https://doi.org/10.1016/j.conbuildmat.2010.06.090

Al-Jabri KS, Hisada M, Al-saidy AH, Al-oraimi SK. Performance of high strength concrete made with copper slag as a fine aggregate. Construction and Building Materials. 2009; 23: 2132-2140 https://doi.org/10.1016/j.conbuildmat.2008.12.013

Alp I, Deveci $H$, Süngün $H$. Utilization of flotation wastes of copper slag as raw material in cement production. Journal of Hazardous Materials. 2008; 159(2-3): 390-395 https://doi.org/10.1016/j.jhazmat.2008.02.056

Ambily PS, Umarani C, Ravisankar K, Ranjan $\mathrm{P}$, Bharatkumar $\mathrm{BH}$, lyer NR. Studies on ultra high performance concrete incorporating copper slag as fine aggregate. Construction and Building Materials. 2015; 77: 233-240 https://doi.org/10.1016/j.conbuildmat.2014.12.092

Ayano T, Sakata K. Durability of concrete with copper slag fine aggregate. Special Publication. 2000; 192: 141-158

Bamonte P, Gambarova PG. Properties of concrete required in nuclear power plants. In: Infrastructure Systems for Nuclear Energy. NY, USA: Chichester, UK: John Wiley \& Sons, Ltd; 2014: 409-438.

Baran T, Glinicki MA, Jóźwiak-Niedźwiedzka D. The properties of special cements for shielding constructions in nuclear power plants. Cement, Wapno, Beton. 2016; 21 (83): 207-215

Brandt AM. Application of concrete as a material for anti- radiation shielding - a review. Cement, Wapno, Beton. 2013; 18(80): 115-132

Brandt AM, Jóźwiak-Niedźwiedzka D, Nowowiejski G, Denis P. Wyniki badania betonu ostonowego z kruszywem magnetytowym [Test results of concrete with magnetite aggregate for shields against radiation]. In: Dni Betonu.; 2014: 839-850.

Brandt AM, Marks M. Optimization of the material structure and composition of cement based composites. Cement and Concrete Composites. 1996 https://doi.org/10.1016/0958-9465(96)00018-2

Dąbrowski M, Gibas K, Brandt AM, Glinicki MA. Wpływ kruszyw specjalnych na porowatość i przepuszczalność betonów ostonowych [The effect of special aggregates on the porosity and permeability of shielding concrete]. Journal of Civil Engineering, Environment and Architecture. 2016; 63: 97-106

Glinicki MA. Długotrwała funkcjonalność betonu w konstrukcjach osłonowych elektrowni jądrowych [Longterm performance of concrete in shielding structures of nuclear power plants]. Warszawa: IPPT PAN; 2015

Jaskulski R, Kubissa W, Koteš P, Brodňan M. Predicting of the compressive strength of RCA concrete. MATEC Web of Conferences. 2017

Koper A, Koper M, Kubissa W. Determining concrete composition on recycled aggregates. Key Engineering Materials. 2015; 677(1): 266-272

Kubissa W. Sorpcyjność betonu [Concrete sorptivity]. Warszawa: Oficyna Wydawnicza Politechniki Warszawskiej; 2016

Kubissa W, Glinicki MA. Influence of internal relative humidity and mix design of radiation shielding concrete on air permeability index. Construction and Building Materials. 2017; 147: 352-361 https://doi.org/10.1016/j.conbuildmat.2017.04.177

Kubissa W, Jaskulski R. Measuring and Time Variability of The Sorptivity of Concrete. Procedia Engineering. 2013; 57: 634-641. https://doi. org/10.1016/j.proeng.2013.04.080

Kubissa W, Jaskulski R, Simon T. Surface blast-cleaning waste as a replacement of fine aggregate in concrete. Architecture Civil Engineering Environment. 2017; 3: 89-94. https://doi. org/10.21307/acee-2017-038

Kurtis KE, Xi Y, Glinicki MA, Provis J, Giannini ER, Fu T. 
Can We Design Concrete to Survive Nuclear Environments? Concrete International. 2017; 39(115): 53-59

Lim YK. Shielding Effectiveness of Magnetite Heavy Concrete on Cobalt-60 Gamma-rays. Journal of the Korean Nuclear Society. 1971; 3(2): 65-75

Meenakshi Sudarvizhi S, Ilangovan R. Performance of copper slag and ferrous slag as partial replacement of sand in concrete. International Journal of Civil and Structural Engineering. 2011; 1(4): 918-927

Ouda AS. Development of high-performance heavy density concrete using different aggregates for gamma-ray shielding. Progress in Nuclear Energy. 2015; 79: 48-55. https://doi.org/10.1016/j.pnucene.2014.11.009

Piotrowski T, Gryziński MA. Ocena efektywności nowej generacji betonów ostonowych przed promieniowan- iem jonizującym w oparciu o pomiary we wzorcowych polach promieniowania [Effectiveness evaluation of new generation shielding concrete against ionizing radiation based on measurements in standard radiation fields]. Czasopismo Inżynierii Lądowej, Środowiska i Architektury. 2016; 63(1): 141-148

Rzechuta J. Gospodarcze wykorzystanie odpadowego ścierniwa z żużla pomiedziowego [Economic use of waste abrasive from copper slag]. In: Łuszczkiewicz A, ed. Fizykochemiczne Problemy Mineralurgii, zeszyt 28. Wrocław: Politechnika Wrocławska; 1994: 207-218

Saferna M, Kaszuba S. Betony o właściwościach specjalnych [Concrete with special properties]. In: V Sympozjum Naukowo-Techniczne "Reologia w technologii betonu". Gliwice; 2003: 15-29.

\section{WOJCIECH KUBISSA \\ Assist. Professor \\ Warsaw University of Technology, Faculty of Civil Engineering, \\ Mechanics and \\ Petrochemistry \\ Main research area \\ Sustainable development in concrete technology, Materials engineering, Civil engineering}

\section{Address}

17 Łukasiewicza St., 09400 Płock, Poland Tel. +48-242626254 E-mail: wojciech. kubissa@pw.edu.pl
ROMAN JASKULSKI

Assist. Professor

Warsaw University of Technology, Faculty of Civil Engineering, Mechanics and Petrochemistry

\section{Main research area}

Thermal properties of concrete, Sustainable concrete materials, Recycling and re-use of industrial waste in cement composites

\section{Address}

17 Łukasiewicza St., 09-400 Ptock, Poland Tel. +48-243672182

E-mail: roman. jaskulski@pw.edu.pl

\section{PUI-LAM NG \\ Adjunct Professor \\ Vilnius Gediminas \\ Technical University, \\ Faculty of Civil \\ Engineering}

Main research area

Sustainable concrete materials and structures, Concrete science and nanotechnology, High-performance cementitious materials

\section{Address}

Sauletekio Al. 11, Vilnius LT-10223,

Lithuania

Tel. +370-62423921 /

$+852-95875310$

E-mail:

irdngpl@gmail.com

\section{JIAJIAN CHEN \\ Assoc. Professor \\ Foshan University, Department of Civil Engineering}

\section{Main research area}

High-performance concrete, Environmentallyfriendly concrete

\section{Address}

18 Jiangwan Rd, Foshan City, Guangdong Province, China Tel. +86-13450891042

E-mail: chenjiajian@ fosu.edu.cn

\section{About the Authors}

